\title{
Isolation and characterization of an extracellular polymer closely related to flocculation of activated sludge
}

Junichi Tsuge $^{1}$ and Masuo Nakano ${ }^{2}$

\author{
${ }^{1}$ Sapporo Otani Junior College \\ N16, E9, Higashi-ku, Sapporo, 065-8567 \\ E-mail: junichi_tsuge@sapporo-otani.ac.jp \\ ${ }^{2}$ Faculty of Dairy Science, Rakuno Gakuen University \\ 582 Bunkyodai Midori-machi, Ebetsu, 069-8501
}

\begin{abstract}
The present study was conducted to obtain a bioflocculant from activated sludge by a simple procedure. An extracellular polymer mainly composed of protein was extracted by sonication from an activated sludge suspension. The polymer exhibited flocculating activity for kaolin clay, activated charcoal, and muddy water (when cations were present), and stimulated reflocculation of deflocculated sludge. Flocculating activity for kaolin clay was related to a concentration of the polymer below $10 \mathrm{ppm}$. The activity was significantly affected by $\mathrm{pH}$ since in basic buffer the activity was inhibited completely while in acidic buffer it was increased. When the polymer was digested with pronase, flocculating activity significantly decreased, although the activity was not affected by heat treatment at $100^{\circ} \mathrm{C}$ for $5 \mathrm{~min}$. These results suggest that flocculating activity is mainly due to the portion of heat stable protein in the polymer. The results obtained in the present study suggest that the isolation of new biodegradable and economical flocculants from activated sludge is feasible.
\end{abstract}

\section{Key words:}

activated sludge, extracellular polymer, flocculating activity

\section{Introduction}

In the activated sludge process, extracellular polymers produced by floc-forming microorganisms in sludge play an important role in floc formation and in the adsorption of organic or inorganic pollutants. The extracellular polymers, which are extremely 
viscous in solution, are mainly composed of polysaccharides, although proteins and nucleic acids from cell autolysis may be present (Stoveland and Lester, 1980; Lester, 1983).

Various flocculating agents involving organic and inorganic compounds are widely used in wastewater treatment, dredging, and fermentation industries. However, some of these substances such as inorganic compounds (e.g. heavy metals) or synthetic high molecular weight organic compounds (e.g. polyacrylamide) might cause secondary environmental pollution. From this viewpoint, biodegradable and nonhazardous flocculating agents obtained from natural sources are needed. Takagi and Kadowaki (1985a, b) obtained a flocculant that aggregated several suspended solids in aqueous solution from the culture filtrate of Paecilomyces sp.-1, and explained that this material was a polysaccharide composed of galactosamine. Kurane et al. (1986) extracted a flocculant from the culture filtrate of Rhodococcus erythopolis, and its aggregation activity was significantly increased by cations such as $\mathrm{Ca}^{2+}$. Dermlim et al. (1999) also showed that an acidic polysaccharide produced by Klebsiella sp. possessed the ability to flocculate kaolin suspension in the presence of $\mathrm{CaCl}_{2}$. Bar-or and Shilo (1987) showed that a flocculant produced by Phormidium was a sulfated heteropolysaccharide to which fatty acids and proteins were bound.

Although many previous studies about bioflocculants have been conducted with pure cultures of microorganisms as previously mentioned, flocculants obtained from natural activated sludge have not been well investigated. If a strong flocculant could be obtained from natural activated sludge, it would be economical and it might bring about the effective use of excess sludge. The present study was conducted to obtain a bioflocculant from natural activated sludge. An extracellular polymer was extracted from an activated sludge suspension and was characterized because an extracellular polymer closely related to flocculation of activated sludge would be useful as a flocculating agent.

\section{Materials and Methods}

\section{Activated sludge samples.}

Activated sludge samples were collected from the aeration tank of Obihiro-south local domestic sewage treatment plant. Samples were stored at $4^{\circ} \mathrm{C}$ for subsequent experiments.

\section{Extraction of extracellular polymer from activated sludge floc.}

Six hundred milliliters of activated sludge was washed 5 times with distilled water, and 
suspended in $900 \mathrm{ml}$ of water. This activated sludge suspension was sonicated for $10 \mathrm{~min}$ with BRANSONIC 92 sonicator ( $45 \mathrm{kHz}, 425 \mathrm{~W}$ ) and was centrifuged at 8,500 rpm for 30 min. A crude extracellular polymer was obtained by dialysis of the supernatant against distilled water at $4^{\circ} \mathrm{C}$ for $72 \mathrm{~h}$. The dialysate was then lyophilized and stored in a freezer. The lyophilized powder was subjected to gel filtration.

\section{Gel filtration of extracellular polymer.}

Gel filtration of the extracellular polymer was performed through a column $(26 \times 300$ $\mathrm{mm}$ ) of Bio-Gel P-100 previously equilibrated with $10 \mathrm{mM}$ Tris (hydroxymethyl) aminomethane-hydrochloride (Tris-HCl) buffer of $\mathrm{pH}$ 8.0. Elution was done with the same buffer at a flow rate of $9 \mathrm{ml} / \mathrm{h}$ and $5 \mathrm{ml}$ fractions were collected. The void volume of the column was determined by the elution volume of Blue Dextran (Pharmacia). The partially purified polymer obtained from Bio-Gel P-100 column chromatography was used throughout the present study.

\section{Analysis of constituent neutral sugar in extracellular polymer.}

Gas-liquid chromatographic (GLC) analysis of constituent neutral sugar monomers in the extracellular polymer was performed after conversion into their corresponding alditol acetates, using a glass column $(0.3 \times 200 \mathrm{~cm})$ packed with $3 \%$ ECNSS-M at $180^{\circ} \mathrm{C}$ in a gas-liquid chromatograph (Hitachi Model 163). The detection and injection port temperatures were $270^{\circ} \mathrm{C}$ and $300^{\circ} \mathrm{C}$, respectively. One milligram of the polymer was completely hydrolyzed with $0.5 \mathrm{ml}$ of $0.5 \mathrm{~N} \mathrm{H}_{2} \mathrm{SO}_{4}$ in $90 \%$ acetic acid at $80^{\circ} \mathrm{C}$. After $16 \mathrm{~h}$, $0.5 \mathrm{ml}$ of distilled water was added and further allowed to stand at $80^{\circ} \mathrm{C}$ for $5 \mathrm{~h}$. The alditol acetates were prepared by the reduction of the hydrolyzed sugars with sodium borohydride followed by acetylation with pyridine/acetic anhydride 1:1 (v/v) at room temperature overnight in a sealed test tube under $\mathrm{N}_{2}$ gas.

\section{Evaluation of flocculating activity of extracellular polymer.}

Kaolin clay, activated charcoal, muddy water, silica gel (Wakogel B-5) and deflocculated sludge were used for the flocculating test. Muddy water was prepared as follows: $500 \mathrm{~g}$ of soil was washed 3 times with distilled water and suspended in 1,000 $\mathrm{ml}$ of water. The mixture was allowed to stand for 10min and the supernatant was collected and used for the flocculating test. Deflocculated sludge was prepared by letting $75 \mathrm{ml}$ of activated sludge to be suspended in $225 \mathrm{ml}$ of distilled water followed by sonication for $3 \mathrm{~min}$. The sludge suspension was centrifuged at $1,000 \mathrm{rpm}$ for $5 \mathrm{~min}$ to remove the remaining floc. The supernatant was further centrifuged at $8,500 \mathrm{rpm}$ for $30 \mathrm{~min}$ to collect deflocculated cells. The deflocculated cells were washed 3 times with distilled water. The polymer solution was added to these suspensions prepared in distilled water or the water 
containing $1 \mu \mathrm{M} \mathrm{MgCl}_{2}$ and $1 \mu \mathrm{M} \mathrm{FeCl}_{2}$ at $2.5 \mathrm{ppm}$ final concentration in a test tube. After standing the mixtures for $3 \mathrm{~min}$, flocculating activity was estimated visually. To estimate the concentration of the polymer, $2 \mathrm{ml}$ of kaolin clay suspension $(5,000 \mathrm{ppm})$ was mixed with the polymer solution at final concentrations of zero to $12.5 \mathrm{ppm}$. After sufficient shaking, absorbance at $660 \mathrm{~nm}\left(\mathrm{~A}_{660}\right)$ was measured. The activity was expressed as the extent of flocculation calculated by the following formula.

Extent of flocculation $(\%)=(A-B) \times 100 / A$

$A: A_{660}$ of the total mixed liquor

$B: A_{660}$ of the upper layer

\section{Effect of $\mathrm{pH}$ on flocculating activity.}

Kaolin clay and activated charcoal suspensions $(5,000 \mathrm{ppm})$ prepared in buffers adjusted to $\mathrm{pH} 2.5 \sim 10.8\left(\mathrm{pH} 2.5 \sim 8.2,0.1 \mathrm{M}\right.$ citrate-0.2 $\mathrm{M} \mathrm{Na}_{2} \mathrm{PO}_{4} ; \mathrm{pH} 9.3 \sim 10.8,50 \mathrm{mM}$ $\mathrm{Na}_{2} \mathrm{~B}_{4} \mathrm{O}_{7}-0.1 \mathrm{M} \mathrm{NaOH}$ ) were mixed with the polymer solution at a final concentration of 5 $\mathrm{ppm}$ to estimate the effect of $\mathrm{pH}$. After $3 \mathrm{~min}, \mathrm{~A}_{660}$ was measured and the extent of flocculation was calculated.

\section{Pronase digestion of extracellular polymer.}

Forty milligrams of the extracellular polymer was dissolved in $40 \mathrm{ml}$ of $10 \mathrm{mM}$ Tris-HCl ( $\mathrm{pH}$ 8.0), containing $0.03 \% \mathrm{NaN}_{3}$ and $0.0025 \%$ chloramphenicol. The mixture was treated with $2 \mathrm{mg}$ pronase at $37^{\circ} \mathrm{C}$ for $72 \mathrm{~h}$. The pronase-digested extracellular polymer was obtained by purification of this reaction mixture using Bio-Gel P-100 column chromatography. The effect of pronase digestion on flocculating activity was estimated with kaolin clay suspension as previously described.

\section{Heat treatment of extracellular polymer.}

The extracellular polymer was dissolved in distilled water at a concentration of $0.5 \mathrm{mg} / \mathrm{ml}$ and heated at $100^{\circ} \mathrm{C}$ for $5 \mathrm{~min}$. The estimation of flocculating activity for kaolin clay was performed using the procedure described above.

\section{Other analyses.}

Total saccharide was determined using the anthrone- $\mathrm{H}_{2} \mathrm{SO}_{4}$ method (Ough, 1964) with a glucose/galactose 1:1 standard. Uronic acid was determined using the method of Blumenkrantz and Hansen (1973) with a glucuronic acid/galacturonic acid 1:1 standard. Hexosamine was determined by the method of Blix (1948) with a glucosamine standard. Phosphorus was determined using the molybdenum- $\mathrm{H}_{2} \mathrm{SO}_{4}$ method (Schinttger et al., 1959). Protein was determined according to the method of Lowry et al. (1951) using a standard of bovine serum albumin. Nucleic acid and protein content in the gel filtration 
eluate were determined by measuring the absorbance at $260 \mathrm{~nm}$ and $280 \mathrm{~nm}$, respectively. All analyses were performed in triplicate.

\section{Chemicals.}

Bio-Gel P-100 was the product of Bio Rad Laboratories. Blue Dextran was the product of Pharmacia Fine Chemicals. Pronase was obtained from E. Merck, Dramstadt. ECNSS-M was obtained from Gas-Chro Kogyo Co. Tokyo. Silica gel (Wakogel B-5) was obtained from Wako Pure Chemical Industries. Other chemicals used in this study were of reagent grade.

\section{Results and Discussion}

\section{Extraction and partial purification of extracellular polymer.}

The floc was satisfactorily deflocculated within $10 \mathrm{~min}$ by sonication of the activated sludge suspension. Accompanying deflocculation, light yellow and extremely viscous substances were released into the aqueous phase. A total of $274.8 \mathrm{mg}$ of crude extracellular polymer was obtained from $600 \mathrm{ml}$ of activated sludge by sonication for 10 min. Figure 1A shows the elution profile of the crude extracellular polymer obtained using a Bio-Gel P-100 column. Through gel filtration on this column, both protein and saccharide were eluted in the void volume $(70 \mathrm{ml})$ at the same position as a single peak. Therefore, the molecular weight was higher than $1 \times 10^{5} \mathrm{Da}$. A total of $110 \mathrm{mg}$ of partially purified extracellular polymer was obtained from $274.8 \mathrm{mg}$ of the crude polymer by this procedure. 


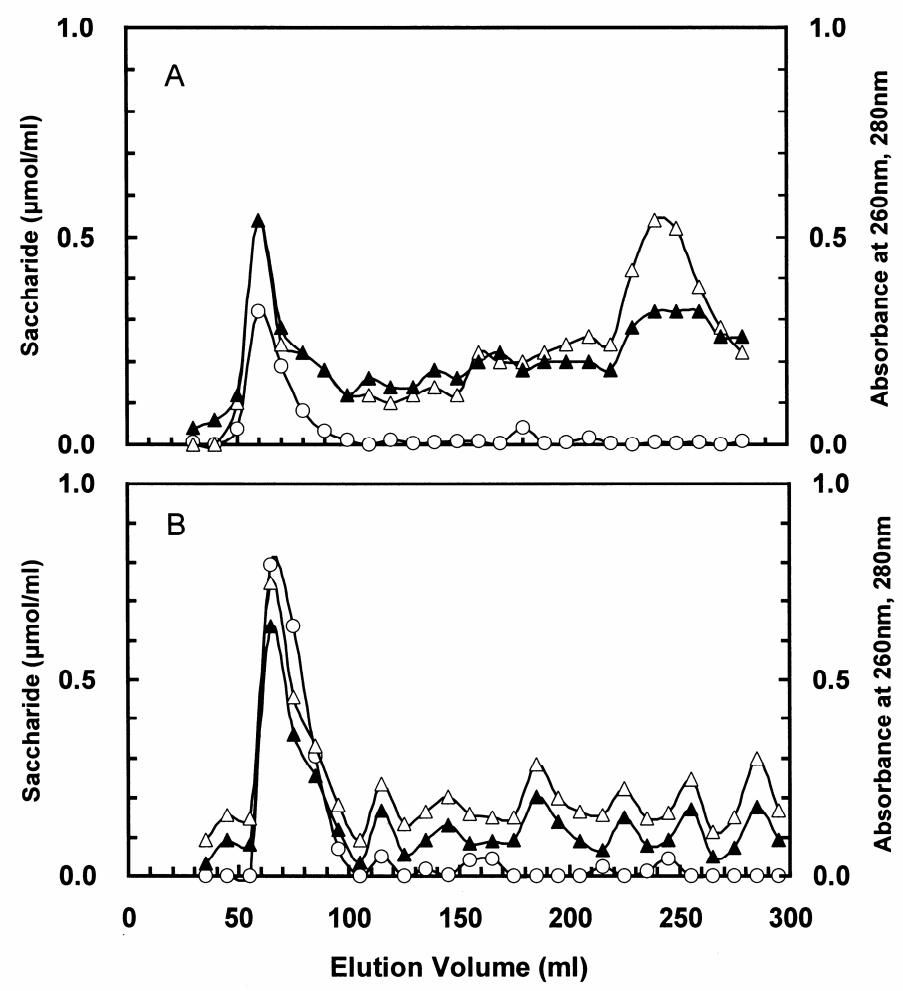

Fig. 1. Bio-Gel P-100 column chromatogram of extracellular polymer extracted from activated sludge.

A; $20 \mathrm{mg}$ of the crude extracellular polymer, $B$; half of the reaction mixture of pronase digestion. Symbols; $\bigcirc$; saccharide, $\triangle$; absorbance at $260 \mathrm{~nm}, \triangle$; absorbance at $280 \mathrm{~nm}$.

\section{Components of extracellular polymer.}

Components of the extracellular polymer were analyzed and the results are summarized in Table 1. These results showed that the polymer was a protein containing polysaccharide. One milligram of the partially purified polymer contained $309.7 \mu \mathrm{g}$ of protein, $160.2 \mu \mathrm{g}$ of neutral sugar, $58.5 \mu \mathrm{g}$ of hexosamine, $30.8 \mu \mathrm{g}$ of uronic acid and $3.8 \mu \mathrm{g}$ of phosphorus. Constituent neutral sugar analysis showed that the neutral sugar was composed of rhamnose, fucose, arabinose, xylose, mannose, galactose and glucose, and their approximate molar ratios were $3: 3: 1: 1: 5: 10: 10$, respectively.

Table 1. Components of extracellular polymer extracted from activated sludge.

\begin{tabular}{ll}
\hline Components & Contents \\
\hline & $\mu \mathrm{g} / \mathrm{mg}$ \\
Protein & 309.7 \\
Neutral Sugar & 160.2 \\
Hexosamine & 58.5 \\
Uronic acid & 30.8 \\
Phosphorus & 3.8 \\
\hline
\end{tabular}




\begin{tabular}{ll}
\hline & Molar ratio \\
Rhamnose & 0.35 \\
Fucose & 0.32 \\
Arabinose & 0.09 \\
Xylose & 0.10 \\
Mannose & 0.51 \\
Galactose & 0.98 \\
Glucose & 1.00 \\
\hline
\end{tabular}

\section{Flocculating activities of the extracellular polymer.}

Flocculating activities of the extracellular polymer are summarized in Table 2. The polymer showed flocculating activity for kaolin clay and activated charcoal suspension, and stimulated reflocculation of deflocculated sludge in distilled water at a polymer concentration of $2.5 \mathrm{ppm}$. Deflocculated sludge also reflocculated without the polymer, suggesting that polymers remained on the surface of microbial cells after sonication. This results to adsorption of polymers onto microbial cells or immediate production of new polymers. When cations were present in the suspension, the polymer showed flocculating activity for muddy water. This shows that the ionic characteristics of extracellular polymers might have important roles in flocculating activity. Our results proved that deflocculation by sonication in a short time was reversible and microbial cells were not injured. The results also agreed with other investigations carried out by Banks and Walker (1977) and Hall (1981). Therefore sonication is an effective method for the extraction of extracellular polymers.

Table 2. Flocculating activity of extracellular polymer extracted from activated sludge.

\begin{tabular}{lll}
\hline \multirow{2}{*}{ Suspended solids } & \multicolumn{2}{l}{ Flocculating activity } \\
\cline { 2 - 3 } & Cations - & Cations + \\
\hline Kaolin clay & + & + \\
Activated charcoal & + & + \\
Muddy water & - & + \\
Silicic acid & - & - \\
Deflocculated sludge & \pm & + \\
\hline
\end{tabular}

Symbols: +; flocculation was observed, \pm ; flocculation was stimulated, -; flocculation was not observed

Figure 2 shows the effect of the concentration of the polymer on the flocculation of kaolin clay. When the polymer concentration was changed from zero to $12.5 \mathrm{ppm}$, the extent of flocculation showed positive correlations to the concentration of the polymer solution added, although a distinct effect was not observed when the polymer concentration was above $7.5 \mathrm{ppm}$. This suggests that an optimum concentration of the bioflocculant for 
flocculating activity exists. Dermlim et al. (1999) also reported that an excess dosage of the polymer isolated from Klebsiella sp. might cause the resuspension of kaolin particles.

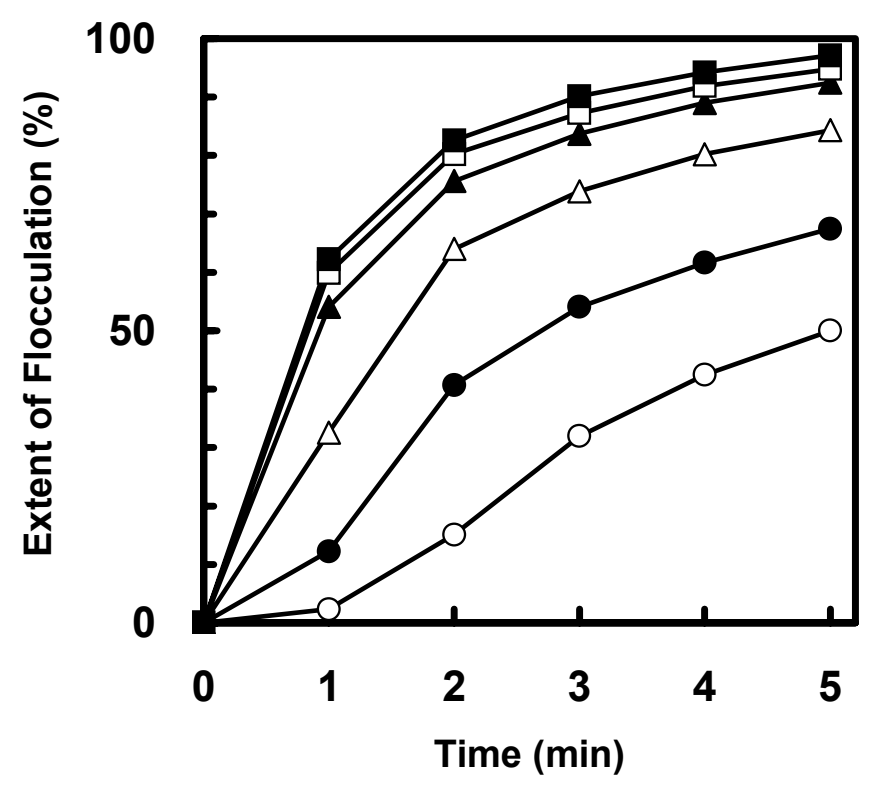

Fig. 2. Effect of the concentration of extracelluar polymer on flocculating activity.

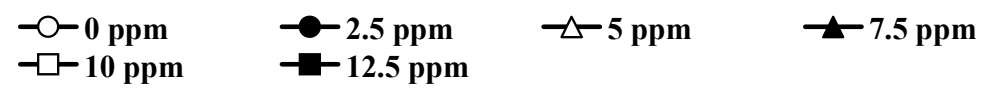

\section{Effect of $\mathrm{pH}$ on flocculating activity.}

Table 3 shows the effect of $\mathrm{pH}$ on flocculating activities of the extracellular polymer for kaolin clay and activated charcoal. The buffer greatly affected the flocculating activity of the polymer, especially with kaolin clay. Compared with the control test, in which the polymer solution was not added, in the acidic region both kaolin clay and activated charcoal flocculated satisfactorily (the flocculation values at $\mathrm{pH} 2.5$ of kaolin clay and activated charcoal were $79.6 \%$ and $67.1 \%$, respectively). On the other hand, in the basic region flocculation did not occur. Flocculation of kaolin clay was also inhibited in the neutral region. This phenomenon is consistent with the results reported by Takagi and Kadowaki (1985a) for Paecilomyces sp.-1 and the results of Nam et al. (1996) for Aspergillus sp. JS-42. Sato and Ose (1980) also reported that viscous substances extracted from activated sludge by $\mathrm{NaOH}$ flocculated kaolin and Escherichia coli suspensions below pH 3. In the acidic region, both kaolin clay and activated charcoal precipitated slightly without the polymer. 
Table 3. Effect of $\mathrm{pH}$ on the flocculating activity of extracellular polymer extracted from activated sludge.

\begin{tabular}{lllll}
\hline \multirow{2}{*}{$\mathrm{pH}$} & \multicolumn{3}{l}{ Extent of flocculation $(\%)$} & \multicolumn{2}{l}{ Activated charcoal } \\
\cline { 2 - 5 } & \multicolumn{2}{l}{ Kaolin clay } & \multicolumn{3}{l}{ Control } & With polymer \\
\cline { 2 - 5 } & Control & With polymer & 19.6 & 67.1 \\
\hline 2.5 & 12.4 & 79.6 & 20.5 & 55.5 \\
3.2 & 0.8 & 26.1 & 9.6 & 41.1 \\
4.3 & 0.8 & 4.2 & 2.7 & 34.0 \\
5.4 & 1.7 & 1.7 & 2.7 & 31.8 \\
6.4 & 1.7 & 1.7 & 2.0 & 32.7 \\
7.2 & 0.8 & 1.7 & 3.4 & 36.6 \\
8.2 & 1.7 & 1.7 & 0.0 & 26.5 \\
9.3 & 0.9 & 0.9 & 0.0 & 20.4 \\
9.9 & 0.8 & 0.8 & 0.0 & 16.3 \\
10.3 & 0.9 & 0.9 & 0.0 & 6.7 \\
10.8 & 0.9 & 2.6 &
\end{tabular}

\section{Pronase digestion and heat treatment of extracellular polymer.}

Initially, $16.8 \mathrm{mg}$ of pronase-digested extracellular polymer was obtained from $40 \mathrm{mg}$ of the intact polymer. Figure 1B shows the elution profile of the pronase-digested polymer obtained using a Bio-Gel P-100 column. As compared with the intact polymer (Fig. 1A), the peak of the absorbance at $280 \mathrm{~nm}$ showing protein fell against that of saccharide. Components of the pronase-digested polymer are shown in Table 4. As compared with that of the intact polymer (Table 1), protein decreased from $309.7 \mu \mathrm{g} / \mathrm{mg}$ to $97.0 \mu \mathrm{g} / \mathrm{mg}$. These results indicated that protein in the polymer was satisfactorily hydrolyzed by pronase digestion.

Table 4. Components of pronase-digested extracellular polymer extracted from activated sludge.

\begin{tabular}{ll}
\hline Components & \multicolumn{1}{c}{ Pronase-digested polymer } \\
\hline & $\mu \mathrm{g} / \mathrm{mg}$ \\
Protein & 97.0 \\
Saccharide & 225.9 \\
Phosphorus & 1.0 \\
\hline
\end{tabular}

Figure 3 compares the flocculating activities of the pronase-digested polymer, the heat-treated polymer and the intact polymer for kaolin clay (each polymer concentration was $5 \mathrm{ppm}$ ). The flocculating activity of the pronase-digested polymer significantly decreased compared to the intact polymer. Heat treatment at $100^{\circ} \mathrm{C}$ for $5 \mathrm{~min}$ did not affect flocculating activity. Willén et al. (2003) reported that the protein had the biggest influence on the surface properties and flocculating ability of the sludge floc. Our results also support the idea that flocculating activity of the polymer is mainly brought about by 
its protein portion and is not due to steric interactions, but to the electrostatic force of heat stable protein in the polymer.

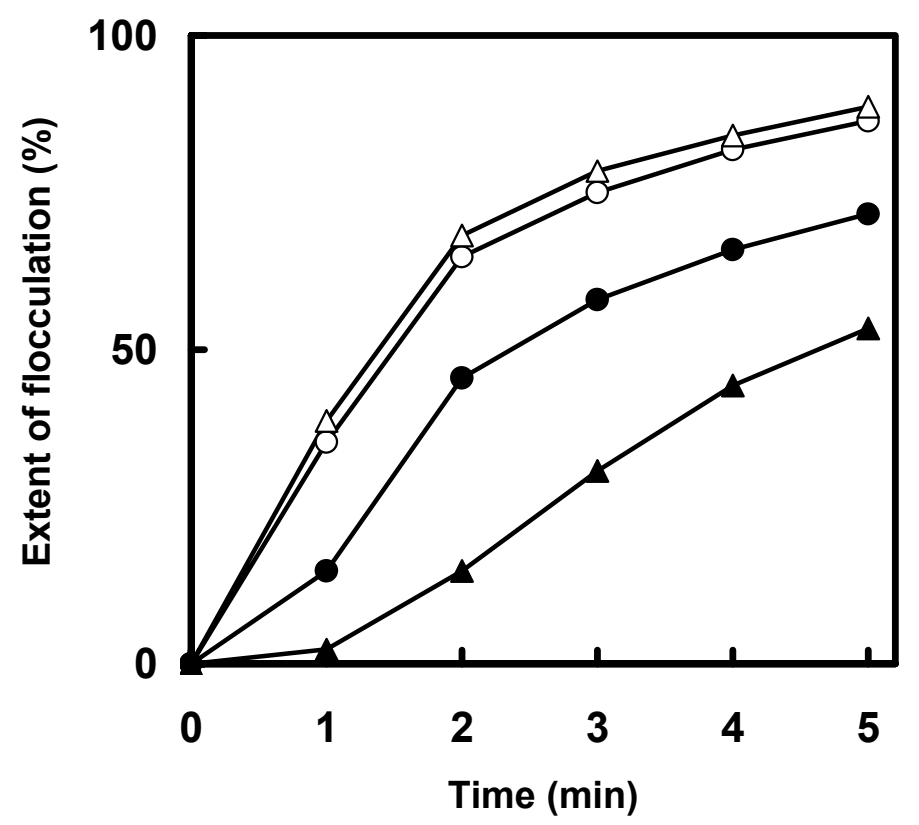

Fig. 3. Effect of pronase-digestion and heat treatment of extracellular polymer on flocculating activity.

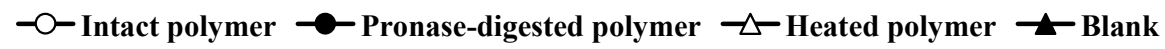

The results obtained in the present study suggest that the isolation of new biodegradable and economical flocculants from activated sludge is feasible.

\section{Conclusions}

This study was conducted to obtain a new bioflocculant from activated sludge. The following conclusions were drawn from the results of the study.

1. An extracellular polymer closely related to flocculation of activated sludge was obtained from the sludge suspension by sonication. The polymer exhibited flocculating activity for several suspensions.

2. Pronase digestion and heat treatment of the polymer showed that the flocculating activity was mainly brought about by heat stable protein in the polymer.

3. The isolation of new biodegradable and economical flocculants from activated sludge is feasible based from the results obtained in the present study. 


\section{References}

Banks, C. J. and Walker, I. (1977) Sonication of activated sludge flocs and the recovery of their bacteria on solid media. J. Gen. Microbiol., Vol.98, 363-368.

Bar-or, Y. and Shilo, M. (1987) Characterization of macromolecular flocculants produced by Phormidium sp. strain J-1 and by Anabaenopsis circularis PCC6720. Appl. Environ. Microbiol., Vol.53, 2226-2230.

Blix, G. (1948) The determination of hexosamines according to Elson and Morgan. Acta Chem. Scand., Vol.2, 467-473.

Blumenkrantz, N. and Asboe-Hansen, G. (1973) New method for quantitative determination of uronic acids. Anal. Biochem., Vol.54, 484-489.

Dermlim, W., Prasertsan, P. and Doelle, H. (1999) Screening and characterization of bioflocculant produced by isolated Klebsiella sp. Appl. Microbiol. Biotechnol., Vol.52, No.5, 698-703.

Hall, T. (1981) Sonication for the study of floc strength and reflocculation of activated sludge. Environ. Tech. Lett., Vol.2, 579-588.

Kurane, R. Takeda, K. and Suzuki, T. (1986) Screening for and characteristics of microbial flocculants. Agric. Biol. Chem., Vol.50, No.9, 2301-2307.

Lester, J. N. (1983) Significance and behavior of heavy metals in waste water treatment process. I . Sewage treatment and effluent discharge. Sci. Total Environ., Vol.30, $1-44$.

Lowry, O. Hosenbrough, N. J., Farr, A. L. and Randall, R. J. (1951) Protein measurement with the Folin phenol reagent. J. Biol. Chem., Vol.193, No.1, 265-275.

Nam, J. S., Kwon, G. S., Lee, S. O., Hwang, J. S., Lee, J. D., Yoon, B. D. and Lee, T. H. (1996) Bioflocculant produced by Aspergillus sp. JS-42. Biosci. Biotechnol. Biochem., Vol.60, No.2, 325-327.

Ough, L. D. (1964) in Methods in Carbohydrate Chemistry (Whistler, R., ed), Vol.IV, pp.91-98.

Sato, T. and Ose, Y. (1980) Floc-forming substances extracted from activated sludge by sodium hydroxide solution. Water Res., Vol.14, No.4, 333-338.

Schnittger, H., Papenberg, K., Gause, E., Czok, R., Bucher, Th. and Adam, H. (1959) Chromatographic phosphaltiger metabolite eines menschlichen leberpunktats. Biochem. Z., Vol.332, 167-185.

Stoveland, S. and Lester, J. N. (1980) A study of the factors which influence metal removal in the activated sludge process. Sci. Total Environ., Vol.16, No.1, 37-54.

Takagi, H. and Kadowaki, K. (1985a) Flocculant production by Paecilomyces sp. Taxonomic studies and culture conditions for production. Agric. Biol. Chem., Vol.49, No.11, 3151-3157. 
Takagi, H. and Kadowaki, K. (1985b) Purification and chemical properties of a flocculant produced by Paecilomyces. Agric. Biol. Chem., Vol.49, No.11, 3159-3164.

Wilén, B.-M., Jin, B. and Lant, P. (2003) The influence of key chemical constituents in activated sludge on surface and flocculating properties. Water Res., Vol.37, No.9, 2127-2139. 